\title{
Improve Student Skills in Read Understanding Text Explanation with Using the SQ3R Method
}

\author{
Delina R., Hatma Heris Mahendra, Riga Zahara Nurani \\ Universitas Perjuangan Tasikmalaya \\ delinar04@gmail.com
}

\section{Article History}

accepted 05/11/2020

approved $10 / 11 / 2020$

published 01/02/2021

\begin{abstract}
The research has problem less reading comprehension ability explanation text in class IV. This research aims to increase reading comprehension ability using SQ3R in text explanation at IV class SDN Nantang. The researcher uses classroom action research. The result shows the use of SQ3R can increase reading comprehension ability in text explanation. Pre-test shows average scores are 45,83 with $27 \%$ complete and $73 \%$ incomplete. Cycle I with average scores are $75,67 \%$ with $60 \%$ complete and $40 \%$ incomplete and cycle II average scores 87,83 with $90 \%$ complete and $10 \%$ incomplete. The result of average is 42 . Reading comprehension ability is 53\%. Based on the increase in pre-test until cycle I and cycle II, the conclusion is SQ3R can increase reading comprehension ability in text explanation at IV class SDN Nantang sub-district Cigalontang regency Tasikmalaya period 2020/2021
\end{abstract}

Keywords: method of SQ3R, reading comprehension, elementary school students, explanation text.

\begin{abstract}
Abstrak
Permasalahan dalam pengambilan data adalah rendahnya keterampilan membaca pemahaman teks eksplanasi dikelas VI. Penelitian ini bertujuan untuk meningkatkan keterampilan siswa dalam membaca pemahaman dengan menggunakan metode SQ3R pada materi teks eksplanasi dikelas VI SDN Nangtang. Metode yang digunakan dalam penelitian ini yakni penelitian tindakan kelas (PTK). Hasil penelitian ini menunjukan bahwa penggunaan metode SQ3R dapat meningkatkan keterampilan membaca pemahaman teks eksplanasi. Pada pratindakan menunjukan nilai rata-rata 45,83 dengan persentase $27 \%$ tuntas dan $73 \%$ belum tuntas, siklus I nilai rata-rata 75,67 dengan persentase $60 \%$ tuntas dan $40 \%$ belum tuntas, dan siklus II nilai rata-rata 87,83 dengan persentase $90 \%$ tuntas dan $10 \%$ belum tuntas. Peningkatan rata-rata yang terjadi sebesar 42 . Sedangkan pada peningkatan persentase sebesar $53 \%$. Berdasarkan peningkatan dari pratindakan hingga siklus I dan siklus II dapat disimpulkan bahwa dengan menggunakan metode SQ3R dapat meningkatkan keterampilan membaca pemahaman teks eksplanasi di kelas VI SDN Nangtang Kecamatan Cigalontang Kabupaten Tasikmalaya Tahun Ajaran 2020/2021.
\end{abstract}

Kata kunci: SQ3R, membaca pemahaman, teks eksplanasi

Social, Humanities, and Education Studies (SHEs): Conference Series https://jurnal.uns.ac.id/shes

p-ISSN 2620-9284

e-ISSN 2620-9292 


\section{PENDAHULUAN}

Pendidikan dasar merupakan salah satu langkah awal dalam membentuk karakter siswa dimana pendidikan dasar ini salah satu syarat untuk melanjutkan pendidikan kejenjang berikutnya baik, SMP, SMA, hingga ke Perguruan Tinggi. Mata pelajaran Bahasa Indonesia merupakan salah satu mata pelajaran yang ada pada pendidikan Sekolah Dasar, karena mata pelajaran Bahasa Indonesia merupakan mata pelajaran yang sangat perlu kita pelajari yang memiliki beberapa keterampilan diantaranya keterampilan berbicara, keterampilan mendengarkan (menyimak), keterampilan membaca dan keterampilan menulis. Menurut Humaira (2012:96) "Bahasa Indonesia adalah salah satu mata pelajaran yang memberikan pengajaran membaca, menulis, mengarang, membaca puisi, mendikte puisi, berbicara atau menceritakan sesuatu". Dengan adanya mata pelajaran Bahasa Indonesia dapat melatih siswa untuk berkomunikasi atau bergagasan yang baik dan benar secara tertulis maupun lisan. Aspek penting dalam Bahasa Indonesia adalah membaca dan menulis. Yang bertujuan untuk mengetahui berbagai informasi yang belum diketahui. Seseorang ingin mengetahui informasi lebih dalam salah satunya dengan cara membaca. Menurut Padmi dalam Radongkir (2016:3) mengatakan bahwa "Membaca merupakan suatu kegiatan awal untuk mendapatkan pemahaman lebih lanjut dari isi bacaannya, sehingga pembaca dapat mencari makna isi bacaan". Keterampilan membaca merupakan salah satu komponen keterampilan berbahasa yang sangat penting untuk diajarkan sejak dini. Sedangkan Menurut Abidin dalam Pratiwi (2015:1) "Membaca pemahaman merupakan istilah yang digunakan untuk kegiatan membaca yang bertujuan memperoleh informasi yang terkandung dalam teks bacaan".

Berdasarkan hasil pengamatan yang telah dilaksanakan dikelas VI SDN Nangtang Kecamatan Cigalontang. Pada saat proses pembelajaran berlangsung, ditemukan permasalahan pada saat guru memerintahkan siswa untuk memahami teks eksplanasi yang sedang mereka baca. Terlihat sebagian siswa masih rendah dalam keterampilan membaca pemahaman teks eksplanasi. Karena pada saat guru memberikan perintah untuk membaca dan mengerjakan soal teks eksplanasi dan menjelaskan kembali apa yang telah dibaca, sebagian siswa masih rendah dalam memahami suatu bacaan dan siswa juga terlihat kurang aktif dalam proses pembelajaran karena penggunaan metode yang konvesionl. Dari jumlah 30 siswa yang membaca teks eksplanasi, hanya 7 siswa atau (23\%) yang sudah mencapai tingkat membaca pemahaman. Pada saat guru memberikan perintah untuk membaca dan mengerjakan soal teks eksplanasi siswa tersebut paham dan bisa menjawab pertanyaan. Sedangakan 23 atau (77\%) siswa lainnya masih terlihat sulit dalam menjawab pertanyaan. Hal tersebut dapat disimpulkan bahwa hanya 7 siswa yang sudah mencapai tingkat membaca pemahaman dan 23 siswa yang belum mencapai tingkat membaca pemahaman atau $23 \%$ dan $77 \%$ tingkat membaca pemahaman dari keseluruhan jumlah siswa

Teks eksplanasi merupakan teks yang berisi mengenai peristiwa atau kejadian alam maupun sosial. Isi teks eksplanasi berdasarkan hasil pengamatan yang bisa dijadikan suatu pembelajaran bagi pembaca. Teks eksplanasi ini terlihat sangat membosankan bagi siswa karena isi teks eksplanasi yang cukup panjang yang membuat siswa kurangnya minat untuk membaca dan tidak semangat ketika membaca suatu bacaan yang cukup panjang. Dengan demikian diperlukannya suatu metode yang cocok untuk masalah tersebut. Metode dalam keterampilan membaca salah satunya adalah metode SQ3R. Metode SQ3R ini merupakan sebuah metode yang lebih mengarahkan kepada salah seorang pembaca untuk melakukan beberapa tahapan-tahapan sebagai berikut: Survey, Question, Reading, Recite dan Review untuk mempermudah dalam proses kegiatan membaca pemahaman. Menurut Huda dalam Radongkir (2016:4) menyatakan bahwa "SQ3R merupakan metode pemahaman yang membantu siswa berpikir tentang teks yang sedang mereka baca". 
Tujuan dalam pengambilan data ini adalah (1) untuk mendeskripsikan perencanaan pembelajaran dengan menggunakan metode SQ3R dalam keterampilan membaca pemahaman. (2) untuk mendeskripsikan pelaksanaan pembelajaran dengan menggunakan metode SQ3R dalam keterampilan membaca pemahaman. (3) untuk mendeskripsikan peningkatan keterampilan membaca pemahaman teks eksplanasi dengan menggunakan metode SQ3R. Perbedaan penelitian ini dengan penelitan terdahulu terletak pada: (1) perbedaan pada objek penelitian antara keduanya, yakni pada penelitian terdahulu Wening Nadzifah melakukan penelitian pada tahun 2016. Sedangkan pada penelitian ini dilakukan pada tahun 2020. (2) Pada penelitian Wening Nadzifah belum ditentukan materi mengenai keterampilan membaca pemahaman. Sedangkan pada penelitian ini sudah ditentukan materi keterampilan membaca pemahaman mengenai materi teks eksplanasi. (3) Pada penelitian Wening Nadzifah tidak menggunakan teknik pengumpulan data wawanaca sedangkan pada penelitian ini menggunakan teknik pengumpulan data wawancara.

\section{METODE}

Metode ini menggunakan metode penelitian tindakan kelas (Classroom Action Research) yang merupakan salah satu bagian dari penelitian tindakan (Action Research). yang dikembangkan oleh Kemmis dan Mc. Taggart. Model penelitian yang dikembangkan oleh kemmis dan Mc.Taggart ini terdiri dari empat komponen pokok yang memiliki langkah-langkah diantaranya: perencanaan (planning), pelaksanaan (acting), pengamatan (observasing) dan refleksi (reflecting). Penelitian ini dilaksanakan di SDN Nangtang Kecamatan Cigalontang Kabupaten Tasikmalaya Tahun ajaran 2020/2021. Populasi sasaran dalam penelitian ini adalah siswa kelas VI SDN Nangtang Kecamatan Cigalontang, Kabupaten Tasikmalaya, sampel pada penelitian ini, siswa kelas VI berjumlah 30 siswa. Terdiri dari 9 siswa perempuan dan 21 siswa laki-laki. Sebelum melaksanakan penelitian, peneliti melakukan observasi terlebih dahulu terhadap pembelajaran Bahasa Indonesia di kelas VI SDN Nangtang. Peneliti menemukan sebuah permasalahan yaitu rendahnya keterampilan membaca pemahaman pada meteri teks eksplanasi. Dikarenakan pada proses pembelajaran masih menggunakan metode konvesional. Peneliti menyiapkan sebuah metode untuk membantu dalam meningkatkan keterampilan membaca pemahaman yaitu dengan menggunakan metode SQ3R pada pembelajaran membaca pemahaman teks eksplanasi. Peneliti melakukan pratindakan dengan memberikan lembar kerja siswa untuk mengetahui keterampilan awal membaca pemahaman siswa. Sebelum melakukan tindakan selanjutnya yaitu siklus I dan siklus II dengan menggunakan sebuah metode yaitu metode SQ3R. Pembelajaran membaca pemahaman teks eksplanasi dengan menggunakan metode SQ3R mengacu pada Rencana Pelaksanaan Pembelajaran (RPP) yang telah dibuat oleh peneliti.

Teknik pengumpulan data pada penelitian ini yaitu, observasi, wawancara dan tes. (1) observasi digunakan untuk mengumpulkan data-data penelitian selama proses pembelajaran berlangsung, dengan menggunakan lembar penilaian RPP dan lembar penilaian pembelajaran. Penilaian pembelajaran yang dilaksanakan oleh peneliti menggunakan instrumen APKG dengan memperhatikan pembelajaran yang dilaksanakan oleh peneliti dalam pengelolahaan pembelajaran menggunakan metode SQ3R yang diisi oleh observer (guru kelas) pada setiap kegiatan-kegiatan pembelajaran berlangsung, (2) wawancara yang dilakukan oleh peneliti adalah wawancara kepada guru kelas dan wawancara kepada salah satu murid mengenai pembelajaran Bahasa Indonesia, (3) Tes yang digunakan adalah tes tulis untuk mengukur keterampilan membaca siswa pada materi teks eksplanasi. 


\section{Perencanaan}

\section{HASIL DAN PEMBAHASAN}

Penelitian ini dimulai dengan pratindakan, siklus I dan siklus II. Penelitian ini bertujuan untuk meningkatkan keterampilan membaca pemahaman teks eksplanasi dengan menggunakan metode SQ3R pada siswa kelas VI SDN Nangtang Kecamatan Cigalontang Kabupaten Tasikmalaya. Keberhasilan peneliti ini ditunjukkan dengan peningkatan skor rata-rata, persentase dan mencapai nilai indikator yang telah ditentukan.

\section{Pelaksanaan}

Pada tahap awal pelaksanaan penelitian diawali dengan melaksanakan pratindakan dengan tujuan untuk mengetahui kondisi siswa sebelum dilakukannya suatu tindakan. Dengan tidak menggunakan sebuah metode tetapi pembelajaran secara konvensional. Pada pelaksanaan siklus I menggunakan sebuah metode SQ3R dengan terstruktur dan baik tetapi kurang maksimal. Untuk itu dilakukan tahap refleksi untuk memperbaiki kekurangan-kekurangan yang ada pada siklus I sehingga pada siklus II kegiatan pembelajaran menggunakan metode SQ3R dapat dilaksanakan dengan baik. Pada siklus I siswa masih kesulitan dalam membuat pertanyaan dan jawaban, serta kesulitan membuat ringkasan atau review dari teks bacaan sehingga guru melakukan tahap refleksi untuk guru memberikan penjelasan lebih lanjut mengenai membuat pertanyaan dan jawaban serta bagaimana membuat ringkasan atau review. Pada siklus II siswa sudah mempu membuat pertanyaan dan jawaban serta ringkasan atau review.

Tabel 1. Rekapitulasi Hasil Nilai Pratindakan, Siklus I \& Siklus II

\begin{tabular}{|c|c|c|c|c|c|}
\hline Aspek & $\begin{array}{c}\text { Nilai } \\
\text { Rata-rata }\end{array}$ & $\begin{array}{c}\text { Jumlah } \\
\text { Nilai }\end{array}$ & Ketuntasan & $\begin{array}{c}\text { Jumlah } \\
\text { Siswa }\end{array}$ & $\begin{array}{c}\text { Persentase } \\
(\%)\end{array}$ \\
\hline \multirow{2}{*}{ Pratindakan } & \multirow[b]{2}{*}{45.83} & \multirow[b]{2}{*}{1375} & Tuntas & 8 & 27 \\
\hline & & & Belum Tuntas & 22 & 73 \\
\hline \multirow{2}{*}{ Siklus I } & \multirow{2}{*}{75,67} & \multirow{2}{*}{2270} & Tuntas & 18 & 60 \\
\hline & & & Belum Tuntas & 12 & 40 \\
\hline \multirow{2}{*}{ Siklus II } & \multirow{2}{*}{87,83} & \multirow{2}{*}{2620} & Tuntas & 27 & 90 \\
\hline & & & Belum Tuntas & 3 & 10 \\
\hline
\end{tabular}

Sumber: Hasil Pengolahan Data

Berdasarkan tabel 1 Pada Pratindakan menunjukan bahwa nilai rata-rata kelas sebesar 45,83 Siswa yang dinyatakan tuntas sesuai dengan indikator yang telah ditentukan sebanyak 8 siswa dengan persentase $27 \%$ dari jumlah siswa keseluruhan. Sedangkan siswa yang belum tuntas sesuai dengan indikator yang ditentukan sebanyak 22 siswa dengan persentase $73 \%$. Siklus I menunjukan bahwa nilai rata-rata menjadi 75,67 . Siswa yang dinyatakan tuntas sesuai indikator yang ditentukan sebanyak 18 siswa dengan persentase 60\% dari jumlah siswa keseluruhan. Sedangkan siswa yang belum tuntas sesuai dengan indikator yang ditentukan sebanyak 12 siswa dengan persentase 40\% Dan pada siklus II menunjukan bahwa nilai rata-rata menjadi 87,83 . Siswa yang dinyatakan tuntas sesuai indikator yang ditentukan sebanyak 27 siswa dengan persentase $90 \%$ dari jumlah siswa keseluruhan. Sedangkan siswa yang belum tuntas sesuai dengan indikator yang ditentukan sebanyak 3 siswa dengan persentase 10\% Dengan demikian bahwa keterampilan membaca pemahan siswa berada pada kategori Sangat baik.

Menurut Royani (2017:299) Hasil nilai akhir dalam kriteria baik apabila hasil akhir siswa mencapai ketuntasan klasikal atau sekurang-kurangnya $85 \%$ dari jumlah siswa dalam kelas KKM. Keberhasilan peneliti ini ditunjukkan dengan peningkatan skor rata-rata, persentase dan mencapai nilai indikator yang telah ditentukan. Berdasarkan pengambilan data yang telah dilaksankan terhadap siswa kelas VI SDN Nangtang yang berjumlah 30 siswa dari pratindakan bahwa diperlukannya sebuah tindakan lebih 
lanjut mengenai keterampilan membaca pemahaman, dengan menggunakan metode SQ3R yang diyakini dapat meningkatkan keterampilan membaca pemahaman. Penelitian ini dilakukan dengan dua siklus masing-masing siklus melakukan satu pertemuan dengan alokasi waktu 2 X 35 menit. Metode SQ3R ini sebelumnya belum pernah digunakan dikelas VI SDN Nangtang. Sehingga hal ini merupakan sebuah metode yang baru bagi siswa. Pada pelaksanaan siklus I sudah dilaksanakan dengan terstruktur dan baik tetapi kurang maksimal. Untuk itu dilakukan tahap refleksi untuk memperbaiki kekurangan-kekurangan yang ada pada siklus I sehingga pada siklus II kegiatan pemblajaran menggunakan metode SQ3R dapat dilaksanakan dengan baik. Pada siklus I siswa masih kesulitan dalam membuat pertanyaan dan jawaban, serta kesulitan membuat ringkasan atau review dari teks bacaan sehingga guru melakukan tahap refleksi untuk guru memberikan penjelasan lebih lanjut mengenai membuat pertanyaan dan jawaban serta bagaimana membuat ringkasan atau review. Pada siklus II siswa sudah mempu membuat pertanyaan dan jawaban serta ringkasan atau review.

Tabel 2. Rekapitulasi Hasil Nilai Pratindakan, Siklus I \& Siklus II

\begin{tabular}{|c|c|c|c|c|c|}
\hline Aspek & $\begin{array}{c}\text { Nilai } \\
\text { Rata-rata }\end{array}$ & $\begin{array}{c}\text { Jumlah } \\
\text { Nilai }\end{array}$ & Ketuntasan & $\begin{array}{c}\text { Jumlah } \\
\text { Siswa }\end{array}$ & $\begin{array}{c}\text { Persentase } \\
(\%)\end{array}$ \\
\hline \multirow{2}{*}{ Pratindakan } & \multirow{2}{*}{45.83} & \multirow{2}{*}{1375} & Tuntas & 8 & 27 \\
\hline & & & Belum Tuntas & 22 & 73 \\
\hline \multirow{2}{*}{ Siklus I } & \multirow{2}{*}{75,67} & \multirow{2}{*}{2270} & Tuntas & 18 & 60 \\
\hline & & & Belum Tuntas & 12 & 40 \\
\hline \multirow{2}{*}{ Siklus II } & \multirow{2}{*}{87,83} & \multirow{2}{*}{2620} & Tuntas & 27 & 90 \\
\hline & & & Belum Tuntas & 3 & 10 \\
\hline
\end{tabular}

Sumber: Hasil Pengolahan Data

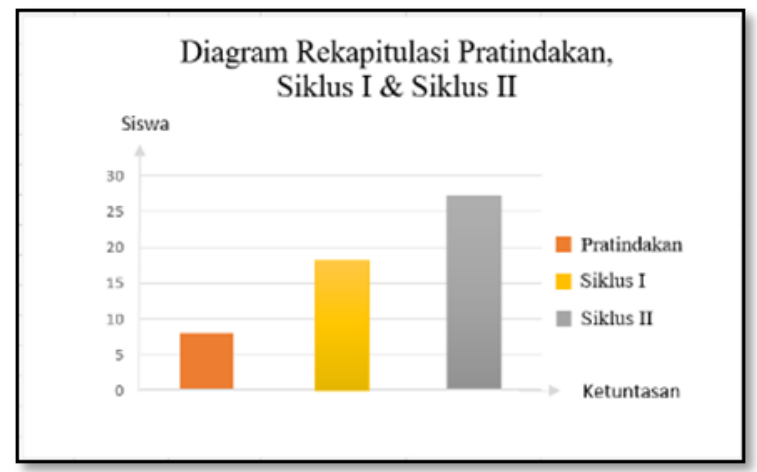

\section{Gambar 1. Diagram Rekapitulasi Pratindakan, Siklus I \& Siklus II}

Berdasarkan pada Tabel. 4 dan Gambar. 1 hasil dari Pada pratindakan, siklus I dan siklus II. Pratindakan menunjukan nilai rata-rata 45.83 Siswa yang dinyatakan tuntas sebanyak 8 siswa atau sebesar $27 \%$ dan siswa yang tidak tuntas sebanyak 22 siswa atau sebesar $73 \%$. Berdasarkan hasil dari pratindakan pada keterampilan membaca pemahaman siswa kelas VI SDN Nangtang perlu ditingkatkan. Adapun pada siklus I menunjukan nilai rata-rata 75,67. Siswa yang dinyatakan tuntas sebanyak 18 siswa atau sebesar $60 \%$ dan siswa yang tidak tuntas sebanyak 12 siswa atau sebesar $40 \%$. Sedangkan pada siklus II menunjukan nilai rata-rata-rata 87,83 . Siswa yang dinyatakan tuntas sebanyak 27 siswa atau sebesar $90 \%$ dan siswa yang tidak tuntas sebanyak 3 siswa atau sebesar $10 \%$. Peningkatan pada rata-rata yang terjadi sebesar 39,66 . Sedangkan pada peningkatan persentase sebesar $60 \%$. Hal tersebut telah memenuhi indikator kriteria keberhasilan pada penelitian ini adalah 85\% tuntas dengan KKM 70. Sehingga pelaksanaan pembelajaran pada siklus II dihentikan. Hal ini 
dikarenakan sudah mencapai rata-rata kelas secara klasikal telah mencapai KKM dan 85\% siswa sudah mencapai KKM yang telah ditentukan dalam penelitian ini.

\section{SIMPULAN}

Perencanaan pembelajaran pada materi membaca pemahaman teks eksplanasi dengan menggunakan metode SQ3R meliputi dua siklus. Terlaksananya perencanaan pembelajaran sesuai dengan penilaian RPP. Dari setiap siklusnya mengalami peningkatan. Siklus I mencapai rata-rata sebesar 3,28, siklus II sebesar 3,65. Dan persentase pada siklus I sebesar 82,14, siklus II sebesar 92,85\%. Perencanaan pembelajaran yang telah dilaksanakan oleh peneliti dengan menggunakan metode SQ3R dapat dikategorikan "Sangat Baik". Seluruh indikator telah terpenuhi, terutama metode pembelajaran yang berpusat pada siswa. Sehingga dapat berpengaruh besar pada pelaksanaan pembelajaran yang bertujuan untuk meningkatkan hasil belajar siswa.

Pelaksanaan proses pembelajaran Bahasa Indonesia pada materi membaca pemahaman teks eksplanasi dengan menggunakan metode SQ3R dikelas VI SDN Nangtang Kecamatan Cigalontang Kabupaten Tasikmalaya Tahun Ajaran 2020/2021. Dapat dikategorikan "Sangat Baik" karena dapat berjalan dengan baik, karena telah di sesuaikan dengan perencanaan yang telah ditentukan dari sebelumnya. Hal tersebut dapat dilihat dari kemampuan atau kualitas peneliti dalam melakukan proses pembelajaran yang telah diamati oleh observer atau guru kelas yang terdapat pada lembar kerja peneliti. Dapat mengalami peningkatan dari siklus I ke siklus II. Adapun hasilnya pada pelaksanaan kinerja peneliti pada siklus I mencapai rata-rata sebesar 3,21 , Siklus II sebesar 3,71. Sedangkan persentase pada siklus I sebesar $91,66 \%$ dan siklus II sebesar $92,85 \%$. Pelaksanaan pembelajaran dengan menggunakan metode SQ3R dapat meningkatkan keterampilan membaca, siswa dalam proses pembelajaran menjadi lebih aktif, serta dapat mempresentasikan hasil kerjanya sehingga aktivitas belajar siswa dapat meningkatkan.

Peningkatan hasil pembelajaran keterampilan membaca pemahaman teks eksplanasi siswa kelas VI SDN Nangtang Kecamatan Cigalontang Kabupaten Tasikmalaya Tahun Ajaran 2020/2021 adalah sebagai berikut: nilai rata-rata pada pratindakan sebesar 45,83 pada siklus I sebesar 75,67 dan pada siklus II sebesar 86,67. Persentase siswa yang mencapai indikator yang telah ditentukan atau persentase yang telah mencapai nilai 70 pada pratindakan sebesar $37 \%$, pada siklus I sebesar $60 \%$ dan pada siklus II sebesar $90 \%$. Hal tersebut menunjukan bahwa pembelajaran membaca pemahaman teks eksplanasi dengan menggunakan metode SQ3R telah memenuhi indikator keberhasilan dalam penelitian ini. Sehingga penelitian ini dapat dikatakan berhasil. Peningkatan pada rata-rata yang terjadi sebesar 42 Sedangkan pada peningkatan persentase sebesar 53\%. Hal tersebut telah memenuhi indikator kriteria keberhasilan pada penelitian ini adalah 85\% tuntas dengan KKM 70. Sehingga pelaksanaan pembelajaran pada siklus II dihentikan. Hal ini dikarenakan sudah mencapai rata-rata kelas secara klasikal telah mencapai KKM dan 85\% siswa sudah mencapai KKM yang telah ditentukan dalam penelitian ini.

\section{DAFTAR PUSTAKA}

Abidin Z. (2017). Meningkatkan Keterampilan Membaca Siswa Kelas XI IPA Melalui Metode SQ3R SMA Negeri satu Bontonompo Kecamatan Bantonompo Kabupaten Gowa. Jurnal Pendidikan. Vol 5, [1]. 56. \{Online\}. (27 Januari 2020).

Humaira. (2012). Pelaksanaan Pembelajaran Bahasa Indonesia Bagi Anak Tunagrahita Ringan Kelas III Di SLB Sabiluna Pariaman. Jurnal IImiah Pendidikan Khusus. Vol 1, [3]. 96. \{Online\}. (23 Januri 2020). 
Pratiwi D. (2015). Penerapan Metode Pembelajaran Timbal Balik Berbasi Media Tayang Video Dalam Pembelajaran Membaca Pemahaman. Universitas Pendidikan Indonesia. Jurnal Pendidikan. \{Online\}. (23 Januari 2020).

Radongkir M. (2016). Keefektifan Metode SQ3R Terhadap Keterampilan Membaca Intensif Siswa Kelas III SDN Ngaliyan 01 Kota Semarang. (Skripsi Pendidikan Guru Sekolah Dasar Universitas Negeri Semarang). \{Online\}. (23 Januari 2020).

Royani A. (2017). Penerapan Teknik Pembelajaran Kooperatif NHT dalam Meningkatkan Pemahaman tentang Bumi Bagian dari Alam Semesta. Jurnal Riset dan Konseptua. \{Online\}. (21 Juli 2020).

Sulistyaningsih, dkk. (2014). Membaca 2. Universitas Terbuka. Tanggerang Selatan. 